\title{
Trophic Relationships Between People And Resources: Fish consumption in an artisanal fishers neighborhood in Southern Brazil
}

\author{
Maísa Castro Sousa ${ }^{1,2}$, Ivan Machado Martins² and Natalia Hanazaki²*
}

\begin{abstract}
The study of dietary consumption is important to understanding the relationship between eating habits and natural resources, which may reflect adjustments and adaptations demanded by local environmental changes. This study aimed to understand the trophic relationships between the local families' diets and the ichthyofauna present in an urban neighborhood of artisanal fishers in southern Brazil (Tijucas, Santa Catarina). Data were collected through semi-structured interviews in 88 households who reported the consumption of 62 types of fish, where the most consumed were the mullet (Mugil spp.) and croaker (Micropogonias furnieri). Fish is still an important source of animal protein for local families. Preferences and aversions observed can be explained by the relationship between environmental factors and cultural aspects that relate to the economic and social context of the community. In the last decade fish consumption was affected by local immigration and by contextual changes affecting local fisheries.

Keywords: Artisanal fishers, ethnozooology, fisheries.
\end{abstract}

\section{INTRODUCTION}

Fishing is an ancient activity and a source of food and employment to many coastal and riverine populations, sustaining local livelihoods and contributing to food security (Bene et al. 2007). Fish accounts for a significative part of the animal protein intake in the world and is a key element to be addressed in food security policies (Bene et al. 2015). Small scale fisheries play an expressive role in this scenario, with about $90 \%$ of all fishing vessels and 22 million fishers (Schuhbhauer and Sumaila 2016). These small-scale fisheries encompass a wide range of characteristics, and usually include artisanal fishing, among other definitions usually delimited in a relative basis (Schuhbhauer and Sumaila 2016).

According to FAO (2014) artisanal fisheries are defined as traditional fisheries involving fishing households, with a small amount of capital and energy, small fishing vessels, making short fishing trips, close to shore, and mainly for local consumption. This definition is opposed to commercial companies and is relative, although artisanal fisheries can use from very simplified technologies until more than $20 \mathrm{~m}$ trawlers, and their catches can be directed to subsistence or commerce, providing for local consumption or export (FAO 2014). In Brazil, artisanal fishing occurs along the entire coast (and also in inland

1 Undergraduate student of Biology, Universidade Federal de Santa Catarina

2 Laboratório de Ecologia Humana e Etnobotânica, Departamento de Ecologia e Zoologia, Universidade Federal de Santa Catarina, Florianópolis, SC, 88010-970, Brazil

* Corresponding author. E-mail adresses: MSC (maisasc_bio@yahoo.com.br), IMM (ivanmmartins@gmail.com),NH(natalia.hanazaki@ ufsc.br) 
waters) and is related to specific socio-economic characteristics of the communities that engage in this activity. Payment occurs through the direct marketing of fish or through middlemen, fisheries or fish stands, in which there may exist other complementary seasonal economic activities (Diegues 1988). In addition, Berkes et al. (2001) argued that this practice has the ability to exploit both the same fishing stocks as large scale fishing industries, as well as a large number of smaller fish stocks near the coast.

The state of Santa Catarina has about 25,000 professionals working in artisanal fisheries, which account for about $30 \%$ of the fish production in the state, excluding from this percentage the portion directly consumed by fishers and their families (Santa Catarina 2004). In many cases, fishing activities contributes to diet diversification of coastal populations, especially when considering the different species consumed in the "fish" category (sometimes including other seafood animals such as mollusks and crustaceans) compared to other protein sources (Hanazaki and Begossi 2003). Thus, the study of fish consumption by these communities is relevant in order to understand the relationship between human populations and the natural resources around them, which allows us to infer about changes and adaptations associated with local environmental transformations (Hanazaki and Begossi 2000).

Several authors highlight the value of traditional ecological knowledge embedded in artisanal fisheries. Traditional knowledge is built from historical and synchronic experience with a given environment, and contributes with information about subjects ranging from fish behavior and ecology (Silvano et al. 2006; Poizat and Baran 1997) to fisheries management (Schafer and Reis 2008; Berkes et al. 2001). The knowledge regarding the preferences and dietary restrictions in relation to fish availability also becomes important, in order to verify and understand consumption patterns and the relationship between fish resources and the community (Hanazaki and Begossi 2006). These factors are important to understand the availability of environmental species or their economic importance and social relationship with the community (Hanazaki and Begossi 2006;
Ramires et al. 2012), and how human populations recognize, use and manage their resources and environments (Hanazaki and Begossi 2003; Ramires et al. 2012).

Coastal marine environments are focus of conflicting management demands. By one side we have to considerer fishing, both artisanal and in other scales, and by the other side it is imperative to consider the need for conservation strategies for marine resources and environments. Marine Protected Areas (MPA) have a dual role of conservation of biological resources but also to contribute to maintaining the health of surrounding ecosystems, which often occurs by spillover effects in nearby environments (Roberts et al. 2001). Thus, fishing and biological conservation priorities cannot be seen as following in antagonistic directions.

The analysis of a human populations' diet can be understood from the perspective of human ecology, as an approach that integrates many aspects of resource use by a population (Hanazaki and Begossi 2003). Models and theories from ecology prove to be very useful and applicable when seeking to understand the relationships between human populations and natural resources, such in the analysis of food niche and trophic levels of consumed items (Begossi et al. 2004).

The relationship between resource use and diet may reflect adjustments to changing environmental situations, which leads to changes in the livelihoods of local inhabitants. Such changes, coupled with cultural and socioeconomic factors, can be seen as a biocultural impact resulting from the abandonment of local production traditions, loss of food sovereignty and local knowledge, reducing the nutritional quality of their diet (Daltabuit and Leatherman 1998). For example, the replacement of food items directly obtained from the environment by industrialized ones may increase the dependence of purchased items and the dependence of a constant source of income. In parallel, the search for external sources of income can replace traditional livelihood activities, undermining the conditions of reproduction of local knowledge.

One concern is the lack of information regarding the total production output generated by 
subsistence fishing, which is often excluded from official statistics of fisheries because it is intended for direct consumption of these families (Cerdeira et al. 1997). It is possible that this fraction, which is not measured, can bring valuable information in understanding the real situation of the pressure exerted on fish stocks (Isaac et al. 2008). This work aimed to investigate the relationships between people and fish resources (ichthyofauna) consumed in a neighborhood of artisanal fishers, which is nearby a Marine Protected Area (MPA). In addition to characterizing and quantifying the major fish species consumed in the community, the preferences and dietary aversions in relation to fish consumption were identified, as well as the local perception on the increase, maintenance or reduction in fish consumption after the creation and enforcement of the MPA.

\section{MATERIAL AND METHODS}

\section{Study Area}

This study was conducted in the neighborhood

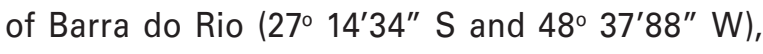
located in the municipality of Tijucas (Santa Catarina, South Brazil), where the mouth of the Rio Tijucas is located and adjacent to Tijucas Bay (Figure 1). Barra do Rio is a neighborhood with urban characteristics, but with a concentration of artisanal fishers. About 400 vessels fish within the bay along the year, mostly for shrimp, and from different neighborhoods in the region. Less than 50 fishers are from Tijucas bay area and have fish (and not shrimp) as their target. These fishers primarily fish in the interior of Tijucas Bay and around a MPA, the Arvoredo Marine Biological Reserve (Martins et al. 2013; Martins et al. 2014).

Tijucas Bay is located west of the Arvoredo Marine Biological Reserve limits and within the buffer zone of this conservation area. This MPA was created about two decades before data collection, and is intended to protect a significant portion of the region's coastal ecosystems and associated natural resources. The management plan of this MPA was drawn a decade after its creation. Fishers and local residents of Tijucas bay did not have a clear notion about when the MPA was created, but they pointed out that the surveillance started about 10 years ago. We assumed that it was during the process of the management plan elaboration that much of the population became aware of the unit. Marchioro and Polette (1998) argued that the prohibition of fishing in certain areas close to the fishing communities, consequently, can generate intensification of fishing activities adjacent to the restricted areas, such as trawl fishing inside the bays of the region. 


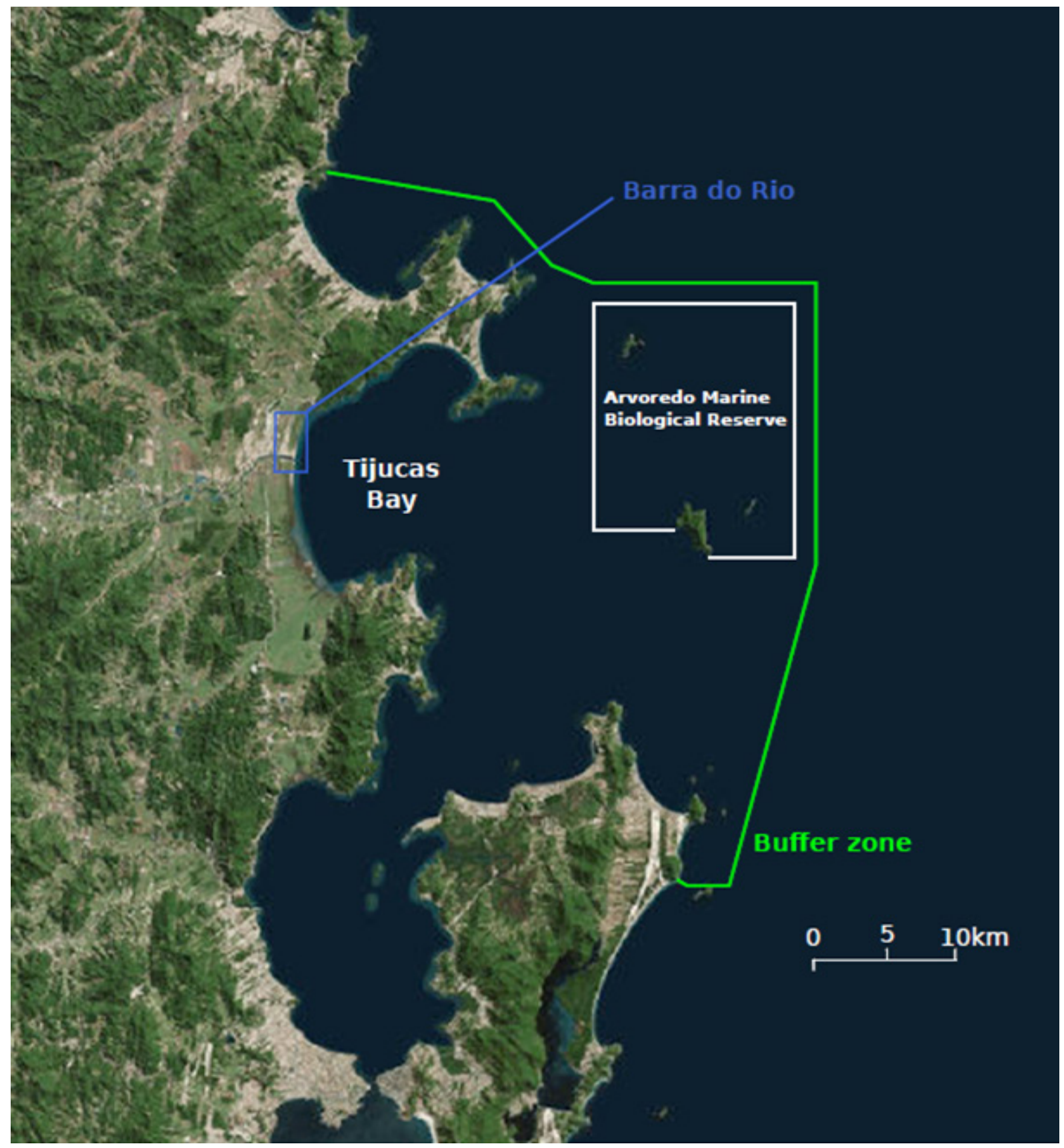

Figure 1. Study site.

\section{Data collection}

Data were collected through semi-structured interviews from a sample of residents in the neighborhood of Barra do Rio, after obtaining the signed prior informed consent from each interviewee. This study was under a major research proposal authorized by Ethics Committee of Federal University of Santa Catarina (CEPSH number 982). In order to access information on fish consumption in the region, interviews were conducted using a form (see Additional file 1, in Portuguese) containing questions about the main fish species consumed, consumption frequency and quantities consumed in the last three meals of the household, other sources protein of animal 
origin consumed, preferences and restrictions of fish consumption, perception of the increase, maintenance or reduction of fish consumption after the enforcement of the regulations of the Arvoredo Marine Biological Reserve (last 10 years), and the origin of fish consumed in the locality.

Data were collected between late winter and early spring for 10 nonconsecutive days in the months of August and September 2011. We interviewed collaboartors from about $13 \%$ of households in the neighborhood, estimated at a total of 675 houses, using a sampling error of $15 \%$ (Barbetta 2006). To distribute the sample effort in the neighborhood the area was divided into five similarly sized sections, and households were selected periodically in intervals of 7 to 8 houses in each section. In each household we interviewed one resident over 16 years of age. Interviewees with less than 30 years were not asked about the changes in the last decade (question 12, Additional file 1). For the scientific identification of species cited in the interviews, we used secondary data from the studies of Martins et al. (2013), Martins et al. (2014) and UNIVALI (2008).

Quantitative data were analyzed using descriptive statistics. For a comparison between biomass consumed by households (question 11, see Additional file 1) and reported consumption (question 6, see Additional file 1) we used Pearson correlation coefficient. In this analysis we were contrasting the reported consumption with the actual consumption in the last three meals. For qualitative data the researcher made interpretations and reflections so that the process of understanding the data was not lost (Creswell 2010). For the latter, field notes were essential for archiving information, as advised in Amorozo and Viertler (2010). The notes were grouped into themes, perspectives or problems in order to better understand the core of the researchers statements and to identify patterns (Creswell 2010; Amorozo and Viertler 2010). Interviewees' speeches were identified by the number of the interview (\#) and age of the collaborator in years (y).

\section{RESULTS}

Interviews were conducted in 88 sampling units (households) in the Barra do Rio neighborhood, with around 20 refusals. About a quarter (24\%) of residents surveyed were born in Tijucas, however, most residents $(76 \%)$ came from other places (not born in the region). Data from the Brazilian Institute of Geography and Statistics (Brazil 2010) indicate a population increase in Tijucas of approximately 40\% between 1991 and 2007 . Of the 88 interviews, 62 were women $(70 \%)$. The age of respondents ranged from 16 to 78 years, with a predominance of people aged between 30 and 60 years. The main occupation of the families interviewed were self-employed $(29 \%)$, as masons, mechanics, fishers, and cooks; $26 \%$ were employees of private companies, markets and shops in the region; $24 \%$ were retirees; $5 \%$ civil servants; and $16 \%$ did not provide an answer. More than half of the households had at least one member of the family - not necessarily living in the same household - who practiced fishing. From this number, $59 \%$ are dedicated entirely to fishing, $11 \%$ are partially devoted to it and $30 \%$ occasionally practiced fishing.

The frequency of fish consumption was varied, but just over $50 \%$ of respondents consumed fish once a week or more frequently (Figure 2). Fish is consumed at least once a week by $31 \%$ of respondents, $6 \%$ consumed fish twice a week, $18 \%$ had fish almost every day in their meals, and $1 \%$ consumed fish every day of the week.

According to interviewees fish consumption was observed in $62 \%$ of the meals sampled, considering the last three meals of the 88 families interviewed. This corresponds to a total of 260.1 $\mathrm{kg}$ of fish or $1.56 \mathrm{~kg}$ of fish per family per meal with fish. Average size of families is 3.8 people (standard deviation 1.6), summing an average consumption of 410 grams of fish consumed per person per meal. 


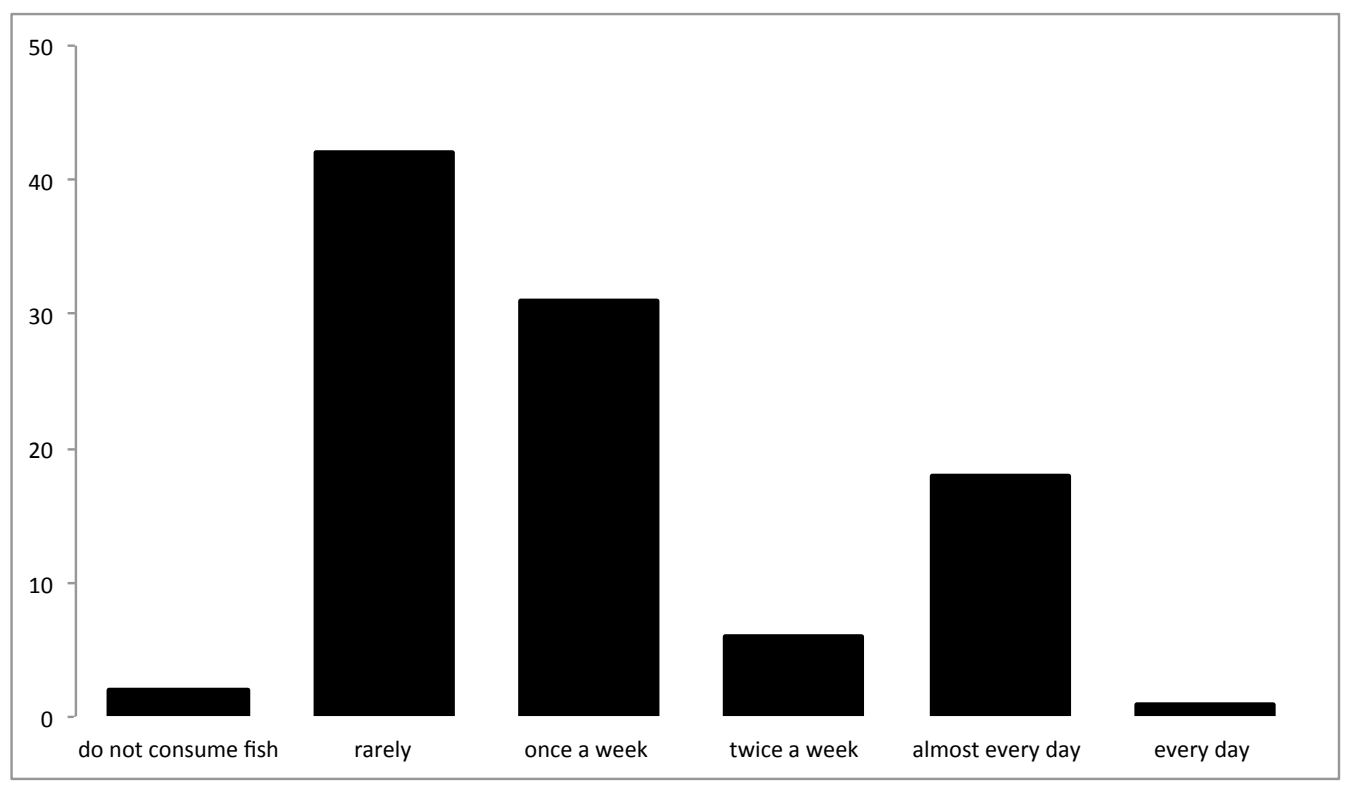

Figure 2. Frequency of fish consumption according to interviewed residents of Barra do Rio,Tijucas, Brazil, 2011. Data in percentage ( $\mathrm{n}=88$ interviews).

The purchase of fish in the region for food consumption was done by $82 \%$ (72) of families; nonetheless from this number approximately $44 \%$ (32) also gained and/or fished for what they consumed. Therefore, it was observed that about $55 \%(48)$ of total respondents earn or fish what they consume and thus they do not solely depended on the market to buy fish for their families. Only $10 \%$ of the interviewees considered that the fish sold in the region was from from Tijucas; $40 \%$ said the fish were caught in nearby regions such as, Itajai, Florianópolis, Bombinhas, Bombas, and the state of Rio Grande do Sul; $32 \%$ could not tell the origin of fish consumed; $10 \%$ said that the fish could come from both outside and inside Tijucas; and 8\% did not answer. Sixteen families (18\%) responded that they do not buy fish in the region, and other six families responded that they do not buy because they always receive fish from relatives, and friends.

In total 62 fish were cited in all questions relating to fish consumption. However, only nine fish were present in more than $5 \%$ of the interviews as the most consumed in the past or present. These fish were the bluefish Pomatomus saltatrix (Linnaeus, 1766) (anchova), catfish Ariidae sp. 1 (bagre), shark Carcharhinidae sp. 1 (cação), sardines (several species of Clupeidae grouped as "charuto" or "sardinha"), croaker Micropogonias furnieri (Desmarest, 1823) (corvina), weakfish Macrodon ancylodon (Bloch \& Schneider, 1801) and Isopisthus parvipinnis (Cuvier, 1830) (pescadinha), mullets Mugil liza Valenciennes, 1836 (tainha), eyespot skate Atlantoraja cyclophora (Regan, 1903), and harvestfish Peprilus paru (Linnaeus, 1758) (Table 1).

When comparing the current fish supply to the previous supply 10 years ago, when the regulations related to the MPA were enforced, the perception about the amount of fish was that this amount increased for $25 \%$ of the respondents, declined for $49 \%$ and for $26 \%$ the supply remained the same. The fish that appeared the most in interviews regarding consumption in the past (about ten years ago) were almost all the same: croaker was present in $41 \%$ of the answers, sardines and mullet in $14 \%$, weakfish in $26 \%$, bluefish in $21 \%$, and shark in $15 \%$ (Table 1). These results demonstrate that during the present study, the majority of fish consumed were practically the same as the fish consumed by the community 10 years ago, which may indicate that there was no drastic change in the composition of consumed fish in the last decade. 
Table 1. Species cited in at least $5 \%$ of the interviews as the most consumed in the past or present $(n=61$ interviews; 18 interviewees with $30 y$ rs old or more did not answered this question). Data in percentage, from interviews in Barra do Rio, Tijucas, Brazil, 2011.

\begin{tabular}{llrr}
\hline \multirow{2}{*}{ Local name } & \multicolumn{1}{c}{ Species } & \multicolumn{2}{c}{ Consumption } \\
\cline { 2 - 3 } corvina & & Present & Past \\
charuto or & Micropogonias furnieri (Desmarest, 1823) & 41 & 39 \\
sardinha & several spp. of Clupeidae & 44 & 43 \\
tainha & & 44 & 43 \\
pescadinha & Mugil liza Valenciennes, 1836 & 26 & 23 \\
Macrodon ancylodon (Bloch \& Schneider, 1801); Isopisthus & 21 & 21 \\
cação & parvipinnis (Cuvier, 1830) & 15 & 11 \\
bagre & Pomatomus saltatrix (Linnaeus, 1766) & 8 & 5 \\
emplastro & Carcharhinidae sp. 1 & 7 & 7 \\
gordinho & Ariidae sp. 1 & 7 & 5 \\
\hline
\end{tabular}

The main reasons for the increase in fish consumption were related to eating habits: the idea that fish are a healthy food and easy to access. Considering that $76 \%$ of respondents were born in other locations, the availability of a new protein source to improve the diet of these families may have been decisive in the incorporation of dietary habits related to fish consumption. In contrast, the decrease in fish consumption, which was reported by $49 \%$ of the interviewees as described above, relates to the loss of artisanal fishing traditions, as well as to the perception of a decrease in the amount of fish available in the community. Table 2 shows some statements collected from the speeches of the interviewed collaborators related to the reasons to increase or to decrease fish consumption.
The relationship between the percentage of consumption reported in interviews and recorded consumption for the last three meals indicates that there is a weak but significant relationship between biomass consumed by households for each fish species and reported consumption of the main species (Pearson correlation $R^{2}=0.496$, $\mathrm{p}=0.03$; Figure 3). Mullet and croaker were the highlighted fish in regards to the quantities consumed, probably due to the seasonality of these resources, which are caught and more available at the time the data collection was done (Martins et al. 2014). The most consumed fish in the last meals were also the most remembered for their current or past abundance, with the exception of the ray Atlantoraja cyclophora (Regan, 1903) (emplastro) and weakfish. 
Table 2. Examples of statements collected from the interviewed collaborators related to changes in fish consumption. Data from 88 interviews in Barra do Rio, Tijucas, Brazil, 2011.

\begin{tabular}{l|l}
\hline $\begin{array}{l}\text { Reasons for the } \\
\text { increase in the fish } \\
\text { consumption }\end{array}$ & $\begin{array}{l}\text { "Because it is healthier and because we receive it, so it's easier. Because to buy it } \\
\text { does not work, it is very expensive" (\#27, 61y) }\end{array}$ \\
\cline { 2 - 2 } $\begin{array}{l}\text { Reasons for the } \\
\text { decrease in the fish } \\
\text { consumption }\end{array}$ & $\begin{array}{l}\text { "Because sometimes we do not have money to buy meat so we fish" (\#66, 45y). } \\
\text { become extinct. Before it was very abundant" (\#17, 78y); }\end{array}$ \\
\cline { 2 - 2 } & $\begin{array}{l}\text { "Because my fishermen uncles who lived with us died, so we end up eating less } \\
\text { fish because we have to buy it" (\#60, 17y) }\end{array}$ \\
\cline { 2 - 2 } & $\begin{array}{l}\text { "Before, you had more time to fish and more fish in the sea. Today there is a lack } \\
\text { of time and fish" (\#76, 48y) }\end{array}$ \\
\hline
\end{tabular}

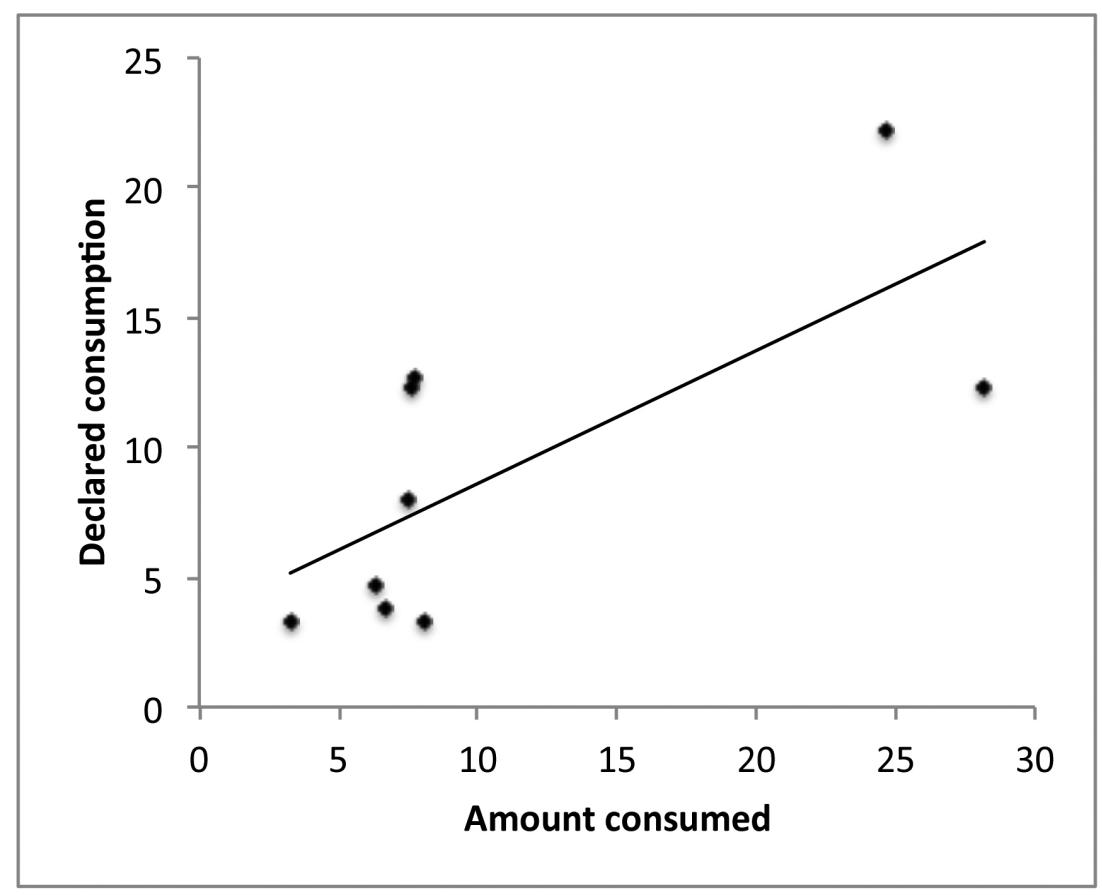

Figure 3. Relationship between the amounts of fish consumed (data in percentage of biomass for nine fish species, total $260.1 \mathrm{~kg}$ ) and declared consumption for the same species (data in percentage of answers). Data from 88 interviews in Barra do Rio, Tijucas, Brazil, 2011.

The fish most frequently cited as preferred (with at least $5 \%$ of citations by the interviewees) were mullet $(27 \%)$, bluefish $(14 \%)$, croaker $(13 \%)$, sardines $(11 \%)$ and shark $(7 \%)$. It is noteworthy that these most preferred species were also found in the past and current consumption of the community. Explanations related to the food preferences on some fish species were made in accordance with the family's customs and habits. Other reasons were because fish is a healthy meat, in general, or because it is simply in accordance with the respondents' palate (Table 3). In the case of mullet, these features were also observed, and some aspects of its behavior were listed as the cause for its flavor. Some fish are simply preferred because of their size and/or quantity of meat such as mullet, bluefish and Spanish mackerel (Scomberomorus brasiliensis Collette, Russo \& Zavala-Camin, 1978) (sororoca), which are all characterized as 'meaty' by some respondents. Another important point 
related to the preference of some fish species was related to the mode of preparation. Croaker was a fish commonly cited as preferred $(13 \%$ of the interviewees), since it is easy to prepare and has a pleasant taste, besides being an abundant fish in the region. It is caught by both artisanal and industrial fleets, which reduces the price for the community and makes it a more feasible purchase.

The fish species related to dietary aversions, that appeared in at least $5 \%$ of the citations by the residents of Barra do Rio, were the catfish (26\%), sardines $(12 \%)$, ray (Batoidea) $(11 \%)$, croaker $(10 \%)$, and shark (9\%). For the dietary aversions and avoidances related to fish the respondents take into account the appearance of diseases or parasites, any sick feeling after consumption, the possibility of harm to people's health, the location of capture, as well as flavor, behavioral, morphological, odoriferous and feeding characteristics of the unvalued fish (dietary restrictions) (Table 3). Most of the explanations for avoiding the consumption the shark and ray were related to their characteristics, which are considered 'loaded' or 'heavy' and is bad for people's health. Catfish (Ariideae) was the fish most often cited as not valued, due to several reasons including the place of capture by fishers, the taste, appearence and smell of the fish, and the type of reproductive and feeding behavior (Table 3).

Table 3. Examples of statements collected from the interviewed collaborators related to food preferences and avoidances. Data from 88 interviews in Barra do Rio, Tijucas, Brazil, 2011.

\begin{tabular}{|c|c|}
\hline \multicolumn{2}{|l|}{ Reasons for preferences } \\
\hline \multirow[t]{2}{*}{$\begin{array}{l}\text { General } \\
\text { health }\end{array}$} & $\begin{array}{l}\text { "people grew up with fish, we have the habit of eating fish since childhood" } \\
(\# 01,62 y) \text { [about fish in general] }\end{array}$ \\
\hline & $\begin{array}{l}\text { "It is good for your health, doctor's say it has Omega } 3 \text { " (\#83, 37y) [about fish in } \\
\text { general] }\end{array}$ \\
\hline $\begin{array}{l}\text { Characteristics and } \\
\text { amount of bones }\end{array}$ & "good fish, strong fish and a little bit of fishbone" (\#71, 39y). [about bluefish] \\
\hline Taste & $\begin{array}{l}\text { "I like the taste, because it comes from the river and then goes to the sea, since } \\
\text { I love river fish I think it has a taste similar to freshwater fish" (\#31, 28 y) [about } \\
\text { mullet] }\end{array}$ \\
\hline Mode of preparation & $\begin{array}{l}\text { "more meaty to roast over coals" (\#27, 61y) [for bluefish] } \\
\text { "good with sauce" (\#27, 61y) [for croaker] } \\
\text { "very good fried" (\#69, 50y) [sardines] } \\
\text { "good breaded" (\#29, 33y) [weakfish] } \\
\text { "is fleshier, and is good to make broth. And is not as sickening" (\#12, 36y) } \\
\text { [Spanish mackerel] }\end{array}$ \\
\hline \multicolumn{2}{|c|}{ Reasons for aversions or avoidances } \\
\hline $\begin{array}{l}\text { Possibility of disease/ } \\
\text { presence of endoparasites. }\end{array}$ & "there is a time that this fish has an animal in its head" (\#78, 46y) [for croaker] \\
\hline "Loaded" or "heavy fish" & $\begin{array}{l}\text { "I am afraid, it can cause problems in the legs, they are loaded fish" (\#28,66y) } \\
\text { "it is bad for you, I'm allergic to these fish, I cannot eat something loaded" (\#65, } \\
63 y \text { ) [for shark and ray] } \\
\text { "produces allergy, it is too loaded" (\#78, 46y) [for catfish] }\end{array}$ \\
\hline Place of capture by fishers & "it is caught in the river and the river is dirty" (\#01, 62y) [for catfish] \\
\hline Taste & "tastes like clay" (\#03, 51y) [for catfish] \\
\hline $\begin{array}{l}\text { Appearance and smell of } \\
\text { the fish }\end{array}$ & $\begin{array}{l}\text { "it looks like a frog, it is very smelly" (\#64,69y) } \\
\text { "strange, disgusting, slippery, messy" (\#13, 32y) [for catfish] }\end{array}$ \\
\hline $\begin{array}{l}\text { Type of reproductive } \\
\text { behavior }\end{array}$ & "I do not like because it clashes inside the mouth" (\#28,66y) [for catfish] \\
\hline Feeding habits & "it is the trash can of the sea, it is a garbage eater" (\#48, 41y) [for catfish] \\
\hline
\end{tabular}




\section{DISCUSSION}

\section{The residents and the fish consumption}

Tijucas bay region is considered a stronghold of artisanal fishers, but most of the inhabitants interviewed believe that the majority of the fish sold has no direct origin with the fishing activity of Tijucas. Nevertheless, fish is a source of animal protein of easy access in the region, due to the presence of a group of artisanal fishers in Barra do Rio that locally provide fish through direct sales and exchanges, fish markets and fish stands. The neighborhood has an easy access to other sources of animal protein, being located in an urbanized area, and also depends on processed foods. This can reflect historical changes in the livelihood ocurred during the growth of the urban area, and the gradual changes in the livelihoods with the abandonment of locally produced foods (Hanazaki and Begossi 2003). The high dependence and the choice to purchase manufactured or processed products have been noted in other studies with artisanal fishing communities (Hanazaki and Begossi 2003; Lopes and Begossi 2006; Silva 2006).

Fish was present in $62 \%$ of sampled meals, which is comparable to more isolated fishing communities in Brazilian coast. Hanazaki and Begossi (2003) observed in artisanal fishing communities of the southern coast of São Paulo that fish are the main source of animal protein present in $32 \%$ of the meals, over poultry $(24 \%)$ and beef $(23 \%)$. Fish consumption in other artisanal fishing communities along the Atlantic coast of Brazil is usually higher, reaching $44 \%$ in Ponta do Almada (Hanazaki and Begossi 2000), 68\% on the island communities of Búzios and Itacuruçá, $65 \%$ in Jaguanum island, and $52 \%$ in Puruba (Begossi et al. 2004). In the community of Ponta do Almada fish were present in $60 \%$ of the meals (Hanazaki and Begossi 2000), which indicates the occurrence of changes in food of animal origin, where beef and chicken replaced fish.

The varied sources of fish at Barra do Rio contributes to keep the percentage of fish consumption higher in other traditonal fishing communities. Exchanges between relatives and neighbors were also observed in other studies on fishers' diets (Hanazaki and Begossi 2003) and were a significant source of fish in these communities. Additionally, fish caught in other localities are locally accessible due to the market chains. This network of trade and marketing reveals that, even though three quarters of families did not consume fish frequently, there is a direct dependence of the resource in the neighborhood, as shown in the fish present in sampled meals. The search for fish from other locations may also be a result of the decrease in artisanal fishers' catches in Tijucas Bay (Martins et al. 2014), as well as the proximity of industrial fleet ports, such as Itajaí and Porto Belo, who commercialize the fish for lower prices than artisanal fishers (Sunye 2006).

\section{Main species consumed}

The majority of the species consumed were produced locally (Martins et al. 2013), with the exception of sardines. The sardines, although not a target species for fishers in the region (Martins et al. 2014; Martins et al. 2013), were often offered at the fishmonger in Tijucas because of the proximity to industrial ports. Sardines are the primary fish resource exploited by industrial fleet in the region (Sunye, 2006).

The perceived changes in the current fish consumption when compared to a decade ago were reflected in the amount and not in the composition of the fish species in local diets. Such changes may be associated with socioeconomic and cultural factors (Hanazaki and Begossi 2003), including the changes in the local fishing industry. The intensification of fishing activity in Tijucas Bay, provoked by restricted access to the Arvoredo Marine Biological Reserve area caused a decrease in the niche occupied by all the fishers in the region (Marchioro and Polette1998; Martins et al. 2014). This alternative area for fishing, adopted by the fishers near the MPA, creates a situation of overfishing of certain species in the Bay, increasing the pressure on other target species and depletion of high productivity ecosystems (Almeida and Vivian, 2011; Martins et al. 2014; Pezzuto et al. 2008), which consequently reduce the fish along the coast, harming the artisanal fishers 
themselves (Cardoso 2001). On the other hand, the creation of a MPA can be positive to local fish stocks, but fishery benefits are still controversial (Buxton et al. 2014; Roberts et al. 2001). Hilborn (2007) argues that fisheries management solutions such as the MPA's creation may not be considered in a isolated way, and the management tools used in fisheries should be expanded in order to reach both biological and economic sustainability.

The decrease in consumption of fish in the local diets may also reflect the abandonment of the customs and livelihoods of the local population, as a result of the problems originating from fishing. The average income of the artisanal fishers in Tijucas Bay is around one to three minimum wages (UNIVALI 2008). According to the local fishers, over the years this wage becomes increasingly insignificant, which forces the families of fishers to change their livelihood, with the gradual abandonment of fishing. Moreover, the interviewees stated that the difficulty of keeping food habits are related to the loss of a family member (in some cases linked to fishing), resource scarcity, the price of fish which is considered too expensive, and product quality. These aspects corroborate with Cardoso's (2001) argument on the situation of artisanal fisheries, which have suffered from the effects of population growth, urbanization, and the consequent increase in cost of living, especially in coastal areas.

For Lopes and Begossi (2006) the relationship between the local fisheries and food demonstrates the dependence on local fish resources and how this dependence varies seasonally. Fish such as the croaker, mullet and bluefish are part of the list of most caught fish in the region, and they show clear signs of decline in their reproduction (Martins et al. 2014; Vasconcellos et al. 2007). In addition to this information, diagnostic data for fishing in Santa Catarina (Santa Catarina 2004) show that these species are among the primarily exploited species by the artisanal fleet in the state. These species are being overfished in a biologically unsustainable manner, due to the pace and intensity of fishing activity on these resources throughout the southern region (Haimovici 1998; Vasconcellos et al. 2007). All these findings call attention to the ongoing process of change in the livelihood and subsistence of all coastal communities that generates a gradual reduction in the perceived availability of fish for these populations. In both rural and urban areas, changes in the way people depend of food such as fish, towards an increasing dependence of industrialized sources of animal protein can alleviate the pressures on wild species, but can have other consequences for local livelihoods and for food security, also contributing to a heavier ecological footprint (Van Vliet et al. 2015). However, production of other sources of animal protein can also indirectly threat other wild species, for example, as a consequence of deforestation for livestock production.

\section{Preferences and dietary restrictions related to the ichthyofauna}

Different characteristics may influence food preferences in relation to animal protein (Hanazaki and Begossi 2006), including the easiness of preparation, fish size and abundance of species. Preferences for cited fish at Barra do Rio are related to aspects such as taste, behavior, capture location, physical characteristics (size, bones) and preparation methods, which are important criteria in the processes of classifying and choosing fish. The manipulation time, which is related to the amount of bones in the fish, is an important variable when choosing which species to consume or to comercialize (Begossi et al. 2012).

The preferences and aversions can be explained by cultural and ecological factors; in other words, by the availability of the resource, the position of the species in the food chain or through the importance of these species in the economy and social relations within the community (Hanazaki and Begossi 2006). The inter-relationship between many of these factors may also result in preferences and dietary restrictions (Ramires et al. 2012). The preference for fish with scales (such as bluefish, sardines, croaker, mullet) is reported in the literature (Hanazaki and Begossi 2000; Hanazaki and Begossi 2006; Ramires et al. 2012; Silva 2006), which was also observed in this study. Croaker and mullet were also found by Begossi et al. (2012) among the most consumed fish in Paraty, Rio de Janeiro state. 
The top preferred fish is mullet (Mugil liza), a migratory fish that lives in the southern area of Brazil, and at its time of reproduction it migrates along the coast towards the north (Seckendorff and Azevedo 2007). This species inhabits marine coastal waters, and both saltwater and freshwater estuaries, where they spend most of their life cycle, however during their reproductive period, they migrate to the open sea (Albieri and Araujo 2010). This migratory behavior from a freshwater environment to a saltwater environment is highlighted in the respondents reports, which they state influences the taste, which was also reported in other studies (Herbst and Hanazaki 2014; Murrieta 1998; Souza and Barrella 2001). The presence of this fish during the winter season generates much expectation in the coastal communities and involves a special organization of fishers (Herbst and Hanazaki 2014), leading to an increase in the consumption of this species during the winter season. The period when data was collected must have been influenced by this seasonality; and we have to consider that any sampling method carries inherent biases unless we could distribute the sampling effort including several conscutive days all over the year. In a study about fisher's behavior Oliveira and Begossi (2011) also used a time scale of analysis focused in a short period of time, when they studied the optimal foraging behavior of fishers, and considered that this approach is usually neglected in other studies on fisheries that prioritize seasonal comparisons. The restrictions of a short period approach certainly limit the conclusions of a study, but also have the potential to avoid the random effect of unpredictable fluctuations, which can happen in activities such as fisheries.

Sardines are a common fish in the fish markets of Barra do Rio and preferred by $11 \%$ of the interviewees because of its flavor and method of preparation. Interestingly, some fishing communities have a food aversion to this type of fish (Hanazaki and Begossi 2006; Silva 2006), often explaining this aversion because of the large amount of bones, which increases the preparation time. In this study, the aversion for sardines (12\%) was explained due to the small size of these fish, the strong taste, and a lot of bones and a small amount of meat, increasing the manipulation time (see also Begossi et al. 2012). By the other hand the preference for sardines for some interviewees may be due to the high availability of the product from the fishing industry, and low commercial value (Sunye 2006).

The explanations offered by respondents for dietary restrictions (related to food taboos) can be perceived through two points of view, either emic (explanations given by the studied individuals) or etic (explanation given by the observer) (Begossi et al. 2004). However, etic explanations can also be offered by local residents in a given context and match those offered by researchers to explain patterns of restrictions, which are observed in a diverse number of human populations in Brazil (Silva 2006).

This study primarily addresses etic aspects related to dietary restrictions of fish consumption in the region, it shows the association of local behavior (taboo) to the ecological knowledge of the food chain. However, this study also provides interpretations of literature on the emic perceptions of food taboos. It was observed that people who are ill or have wounds on the body mainly avoid fish considered to be 'loaded'. This was also observed in the fishing communities of Praia do Bonete, Ilhabela (Silva 2006), Búzios (Begossi 1992) as well as in other fishing communities of the north and south coast of São Paulo (Hanazaki and Begossi 2006). In these studies, apart from the already noted restrictions, the dietary restriction is also for people who are recovering from surgeries and for parturient women. In the Amazon, in Pezzuti's (2004) study the term 'loaded' or reimoso includes a series of attributes such as strong meat, fat and can cause inflammation in people who are sick or have injuries.

In an emic analysis, Begossi (1992) observed that the reasons cited for the dislike of different fish species by the population of fishers from Ilha de Búzios are related to characteristics that affect the sensory systems, such as odor, unsavory appearance and shape of the fish that cause horror and disgust. These characteristics were also evident in the interviews in Barra do Rio, mainly in relation to catfish and ray. The catfish is one of the most caught fish by the Tijucas fishing fleet (Martins et al. 2013), so it is often supplied by the 
fishers, fisheries and fish markets in the region. Hanazaki and Begossi (2006) observed that in São Paulo Bagre the catfish was a preferred food in relation in the fishing community, reflecting a complex interplay of symbolic and cultural factors, as well as materialist or functional factors, such as environmental abundance of this resource in the region. However, opposing this particular observation in São Paulo Bagre, and despite the high availability of this species in the Barra do Rio community, the food taboos related to catfish were expressive and evident in the reports, which can influence the decrease in consumption of this fish in some families. Catfish is commonly avoided by human populations in both the coast and inland of Brazil (Hanazaki and Begossi 2006). The position of these species in the food chain, could be a possible ethicist explanation for the general aversion to catfish, since these fish are usually carnivores or scavengers and therefore are theoretically more prone to accumulation of toxins in their fatty tissues (Hanazaki and Begossi 2006). In his study with fishers on the northern coast of Bahia, Costa-Neto (2001) shows that the catfish species are generally categorized as 'disgusting fish' due to their feeding on human feces.

Hanazaki and Begossi (2006) identified catfish, shark, and ray as poorly valued species by the communities Icapara, Pedrinhas and São Paulo Bagre (state of São Paulo). Rays appear in some studies as avoided fish as well (Costa-Neto 2001; Hanazaki and Begossi 2006). Begossi (1992) defines the term 'loaded' as an animals set of attributes, such as teeth, blood, aggressive behavior, 'strong meat', the presence of fat (grease), among other factors, which can cause inflammation if eaten by someone who is ill or injured. Begossi et al. (2004) emphasizes that the rays are a strongly avoided fish group in the Amazon and the Atlantic Forest, associated with an aversion to elasmobranchs in general, since its meat can deteriorate rapidly. Pezzuti (2004) suggests there is a symbolicmaterialist relationship regarding the aversion to elasmobranchs (rays and sharks), which can be explained by their 'urine smell' and high ammonia concentrations.

The availability of other sources of protein in Barra do Rio due to the proximity to urban centers may also contribute to the persistence of dietary restrictions of some fish. Hanazaki and Begossi (2003) discussed the issue of dietary replacement of fish in some populations, noting that many factors such as modernization, tourism, urbanization, growth, food distribution programs and decrease in the price of other sources of animal protein such as bovine meat and poultry contribute to changes in the local livelihoods. Therefore, populations with high availability to proteins, whatever they may be, generally have more food choices, as opposed to people living in areas with resource scarcity. In other words, restrictions on certain fish consumption from populations with abundant supply of these and other resources are not facts that should surprise the observer.

Another issue discussed by Begossi et al. (2004), shows that the food taboo on some species cannot be considered a behavior that results in the preservation, conservation or sustainability of these resources in one location. At this moment there is no empirical evidence to support this relationship, but we consider that a taboo can or should reduce the predatory pressure on the resource. In this regard, it was observed in Barra do Rio that the rays, despite being considered a taboo food in the region, which could lead to a reduction in the fishers' predatory pressure, are still captured in the region and discarded as bycatch, since there is no demand by the community (Martins et al. 2013). Therefore, even though the communities do not accept some species, their conservation is not regarded, since the fishing activity cannot make an effective selection of individuals that should be captured, resulting in the disposal of the unaccepted fish. In summary, the resource sustainability as a result of food taboos, for some locations, is very difficult to discern or apply, since exploratory fishing activity and predatory fishing continue to exert pressure on fish stocks in general. However, according to the discussion of Begossi et al. (2004), it is deemed necessary a more integrated and systematic approach to verify if the taboos can lead to the conservation of certain species in a given locality, since a predation pressure relief on some species can cause the overfishing of other species. 


\section{CONCLUSIONS}

Fish consumption in the community of Barra do Rio can be considered an important source of animal protein for these families, even with the easy access to industrial and other animal protein sources such as bovine meat and poultry. Fishing activity is still present in at least half of the families interviewed. Due to the latter exchanges of fish among relatives and neighbors is considered important in providing this resource to the community. This reveals that even though three quarters of families do not consume fish frequently, there is still a link to fish resources in the region. However, the consumed fish resources in the neighborhood come from both the artisanal fisheries of the region, and the industrial fleet in the state.

As in other studies, preferences and aversions observed in this study can be explained by the relationship between environmental factors and cultural aspects that relate to the economic and social context of the community. They contribute to the understanding of resource use by this community that is directly linked to fishing.

The overall increased consumption of fish in the last 10 years can be a result of resource availability in the region, since there is a large immigration to the neighborhood, mainly from inland families who did not have easy access to this resource before. Thus, a new protein source incorporated into the family's diet may have been decisive in the inclusion of dietary habits related to fish consumption. In contrast, reducing the consumption of fish may reflect the reduced number of fish available to the community. Such changes may be a consequence of the problematic situation that artisanal fisheries in the region are facing, which can lead to the abandonment of local livelihoods and traditions related to fishing and affect the diet of these populations. The proximity of an MPA and its enforcement a decade ago may have contributed to the availablity of fish for local consumption, although we can not affirm that this relationship is direct, due to the complexity of factors that influence the local consumption of fish.

\section{ACKNOWLEDGEMENTS}

We are grateful to the fishers and to the inhabitants from Barra do Rio for dedicating their time and expertise to this project. Thanks to D.G.Martins for helping during data collection, to FAPESC for financial support (7032/2010-7), and to CNPq for the research productivity scholarship for the third author.

\section{REFERENCES}

1. Albieri RJ, Araújo FG (2010) Reproductive biology of the mullet Mugil liza (Teleostei: Mugilidae) in a tropical Brazilian bay. Zoologia 27: 331-340

2. Almeida TCM, Vivian JM (2011) Macrobenthic associations in a South Atlantic Brazilian enclosed bay: The historical influence of shrimp trawling. Marine Pollution Bulletin 62: 2190-2198

3. Amorozo MCM, Viertler RB (2010) A abordagem qualitativa na coleta e análise de dados em etnobiologia e etnoecologia. In: Albuquerque UP, Lucena RFP, Cunha LVFC (Orgs) Métodos e Técnicas na Pesquisa Etnobiológica e Etnoecológica. 2 edn. NUPPEA, Recife, pp. 67-81

4. Barbetta PA (2006). Estatística Aplicada às Ciências Sociais. Edufsc, Florianópolis

5. Begossi A (1992) Food taboos at Buzios Island (Brazil): their significance and relation to folk medicine. Journal of Ethnobiology 12: 117-139

6. Begossi A, Hanazaki N, Ramos, RM (2004) Food chain and the reasons for fish food taboos among Amazonian and Atlantic forest fishers (Brazil). Ecological Applications 14: 1334-1343

7. Begossi A, Salivonchyk SV, Hanazaki N, Martins IM, Bueloni F (2012) Fishers (Paraty, RJ) and fish manipulation time: A variable associated to the choice for consumption and sale. Brazilian Journal of Biology 72: 973-975

8. Béné $C$, Barange $M$, Subasinghe $R$, Pinstrup-Andersen $P$, Merino G, Hemre G-I, Williams M (2015). Feeding 9 billion by 2050 Putting fish back on the menu. Food Security 7: 261-274

9. Béné C, Macfadyen G, Alison EH (2007) Increasing the Contribution of Small-Scale Fisheries to Poverty Alleviation and Food Security. FAO Fisheries Technical Paper 481

10. Berkes F, Mahon R, McConney P, Pollnac RC, Pomeroy RS (2001) Managing Small-Scale Fisheries: Alternative Directions and Methods. IDRC, Ottawa

11. Brazil (2010). Instituto Brasileiro de Geografia e Estatística. Censo 2010. [http://www.censo2010.ibge.gov.br/amostra/] Accessed 18 March 2016

12. Buxton CD, Hartmann K, Kearney R, Gardner C (2014) When is spillover from marine reserves likely to benefit fisheries? PLOS ONE 9: e107032

13. Cardoso ES (2011) Pescadores Artesanais: Natureza, Território, Movimento Social. Doctoral Thesis, Universidade de São Paulo, São Paulo, Brazil

14. Cerdeira RGP, Ruffino ML, Isaac VJ (1997) Consumo de pescado e outros alimentos pela população ribeirinha do lago grande de Monte Alegre, PA. Brasil. Acta Amazonica 27: 213-228 
15. Costa-Neto EM (2001) A Cultura Pesqueira do Litoral Norte da Bahia: Etnoictiologia. Desenvolvimento e Sustentabilidade. Edufba/Edufal, Salvador/Maceió

16. Creswell JW (2010) Projeto de pesquisa: Método qualitativo, quantitativo e misto. Artmed, Porto Alegre

17. Databuit M, Leatherman TL (1998) The biocultural impact of tourism on Mayan communities. In: Goodman AH, Leatherman TL (Eds) Building a new biocultural synthesis. The Univesity of Michigan Press, Ann Arbor, pp. 317-337

18. Diegues ACS (1988) A pesca artesanal no litoral brasileiro: cenários e estratégias para sua sobrevivência. Proposta 38: 2-24

19. FAO (2014) FAO Term Portal (FAO Fisheries Glossary). Fisheries and Aquaculture Department, FAO. [http://www.fao.org/faoterm/ collection/fisheries/en/] Accessed 25 May 2016

20. Haimovici M (1998) Present state and perspectives for the southern Brazil shelf demersal fisheries. Fisheries Management and Ecology 5: 277-290

21. Hanazaki N, Begossi $A(2000)$ Fishing and niche dimension for food consumption of caiçaras from Ponta do Almada (Brazil). Human Ecology Review 7: 52-62

22. Hanazaki N, Begossi A (2003) Does fish still matter? Changes in the diet of two brazilian fishing communities. Ecology of Food and Nutrition 42: 279-301

23. Hanazaki N, Begossi A (2006) Catfish and mullets: the food preferences and taboos of caiçaras (Southern Atlantic Forest Coast, Brasil). Interciência 31: 123-129

24. Herbst DF, Hanazaki N (2014) Local ecological knowledge of fishers about the life cycle and temporal patterns in the migration of mullet (Mugil liza) in Southern Brazil. Neotropical Ichthyology doi 10.1590/1982-0224-20130156

25. Hilborn R (2007) Reinterpreting the State of Fisheries and their Management. Ecosystems 10: 1362-1369

26. Isaac VJ, Pereira $C$, Almeida MC, Camargo M, Oliveira $C$, Pinheiro RC, Sousa Junior AB, Nunes JLG, Catarino MF, Vale R (2008) Avaliação dos impactos do manejo dos estoques pesqueiros sob diferentes sistemas de gestão. In: Anais da Conferencia do Subprograma de Ciência e Tecnologia Fase II - PPG7. CNPq, Brasilia, pp. 253-256

27. Lopes PFM, Begossi A (2006) Dietary changes over time in a caiçara community from the Brazilian Atlantic Forest. Ecology and Society 11: article 38

28. Marchioro GB, Polette M (1998) Uso do espaço marinho pertencente à Reserva Biológica Marinha do Arvoredo por pescadores artesanais de Zimbros (Bombinhas - SC). In: Anais

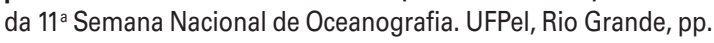
110-112

29. Martins DG, Hanazaki N, Martins IM (2013). Desembarque da pesca artesanal na Barra do Rio (Tijucas, SC). Biotemas 26(2): 237-247

30. Martins IM, Medeiros RP, Hanazaki N (2014) From fish to ecosystems: The perceptions of fishermen neighboring a southern Brazilian marine protected area. Ocean and Coastal Management 91: 50-57

31. Murrieta RSS (1998) 0 dilema do papa-chibé: consumo alimentar, nutrição e práticas de intervenção na llha de Ituqui, baixo Amazonas, Pará. Revista de Antropologia da USP 41: 98-150

32. Oliveira LEC, Begossi A (2011) Last Trip Return Rate Influence Patch Choice Decisions of Small-Scale Shrimp Trawlers: Optimal Foraging in São Francisco, Coastal Brazil. Human Ecology 39: 323-332
33. Pezzuti JCB (2004) Tabus alimentares. In: Begossi A (Org) Ecologia da Mata Atlântica e da Amazônia. Hucitec, São Paulo, pp. 167-186

34. Pezzuto PR, Alvarez-Perez JA, Wahrlich R. (2008). The use of the swept area method for assessing the seabob shrimp Xiphopenaeus kroyeri (Heller, 1862) biomass and removal rates based on artisanal fishery-derived data in southern Brazil: using depletion models to reduce uncertainty. Latin American Journal of Aquatic Research 36: 245-257

35. Poizat G, Baran E (1997) Fishermen's knowledge as background information in tropical fish ecology: A quantitative comparison with fish sampling results. Environmental Biology of Fishes 50 : 435-449

36. Ramires M, Rotundo MM, Begossi A (2012) The Use of Fish in Ilhabela (São Paulo/ Brasil): Preferences, Food Taboos and Medicinal Indications. Biota Neotropica 12: article 1

37. Roberts CM, Bohnsack JA, Gell F, Hawkins JP, Goodridge R (2001). Effects of marine reserves on adjacent fisheries. Science 294: $1920-1923$

38. Santa Catarina, Estado (2004) Diagnóstico da pesca artesanal em Santa Catarina. Relatório. EPAGRI/CEDAP, Florianópolis

39. Schafer AG, Reis EG (2008) Artisanal fishing areas and traditional ecological knowledge: The case study of the artisanal fisheries of the Patos Lagoon estuary (Brazil). Marine Policy 32: 283-292

40. Schuhbauer A, Sumaila UR (2016) Economic viability and smallscale fisheries - A review. Ecological Economics 124: 69-75

41. Seckendorff RW, Azevedo VG (2007) Abordagem histórica da pesca da tainha Mugil platanus e do parati Migil curema (Perciformes: Mugilidae) no litoral norte do estado de São Paulo. Instituto de Pesca - Séries Relatórios Técnicos 28: 1-8

42. Silva MB (2006) Consumo alimentar na comunidade caiçara da Praia do Bonete, Ilhabela, São Paulo. Masters Dissertation, Universidade de Campinas, Campinas, Brazil

43. Silvano RAM, MacCord PFL, Lima RV, Begossi A (2006) When does this fish spawn? Fishermen's local knowledge of migration and reproduction of Brazilian coastal fishes. Environmental Biology of Fishes 76: 371-386

44. Souza MR, BarrellaW (2001) Conhecimento popular sobre peixes numa comunidade caiçara da Estação Ecológica de Juréia Itatins/SP. Boletim do Instituto de Pesca 27: 123-130.

45. Sunye PS (2006) Diagnóstico da pesca no litoral do estado de Santa Catarina. In: IsaacVJ, Martins AS, Haimovici M, Andrigueto Filho JM (Orgs) A pesca marinha e estuarina do Brasil no início do século XXI: Recursos, tecnologias, aspectos socioeconômicos e institucionais Editora Universitária UFPA, Belém, pp. 141-156

46. Townsend $C R$, Begon M, Harper JL (2006) Ecology: from individuals to ecosystems. Blackwell Publishing, Oxford.

47. UNIVALI (2008) Projeto Pesca Responsável na Baía de Tijucas. Relatório Final. [http://siaiacad09.univali.br/pescatijucas] Accessed 18 March 2016

48. Vasconcellos M, Diegues ACS, Sales R (2007) Limites e possibilidades na gestão da pesca artesanal costeira. In: Costa A (Org) Nas redes da pesca artesanal. IBAMA/PNUD, Brasília, pp. $15-84$

49. Van Vliet N, Quiceno-Mesa MP, Cruz-Antia D, Tellez L, Martins C, Haiden E, Oliveira MR, Adams C, Morsello C, Valencia L, Bonilla T, Yagüe B, Nasi R (2015) From fish and bushmeat to chicken nuggets: the nutrition transition in a continuum from rural to urban settings in the Colombian Amazon region. Ethnobiology and Conservation 4:6 doi:10.15451/ec2015-7-4.6-1-12 


\section{ADDITIONAL FILE 1.}

\section{Fish consumption survey in Barra do Rio neighborhood, Tijucas/Santa Catarina - Brazil.}

Date: interviewer: survey code:

Name: Age: Gender: $\square \mathrm{F} \square \mathrm{M}$

Family occupation: Family time living in the neighborhood years.

There is any fisher in the family? $\square$ Yes $\square$ No

Fishing dedication: $\square$ Full time $\square$ Partial $\square$ Sporadic

1) Number of family members?

2) How often your family eats fish?

$\square$ Never $\square$ Rarely $\square$ Once a week $\square$ Almost every day $\square$ Everyday

3) When you don't eat fish, what you eat instead?

$\square$ Meat $\square$ Pork $\square$ Chicken $\square$ Egg $\square$ another seafood $\square$ Other:

4) Do your family livestock animals for consumption?

$\square$ Yes $\square$ No; $\square$ Bovine $\square$ swine $\square$ chicken $\square$ Other:

5) Do you buy fish? $\square$ Yes $\square$ No

a) Who do you buy?

b) Do you know where the fish comes from?

\begin{tabular}{|c|c|c|c|}
\hline & $1^{\circ}$ & $2^{\circ}$ & $3^{\circ}$ \\
\hline 6) What are the most consumed fish in your home? & & & \\
\hline 7) What are the fish that you enjoy most to eat? & & & \\
\hline 7.a) Why do you prefer this fish? & & & \\
\hline 8) What are the fish that you don't like to eat? & & & \\
\hline 8.a) Why? & & & \\
\hline 9) What are the most abundant fish in the community? & & & \\
\hline 10) What are the less abundant fish in the community? & & & \\
\hline $\begin{array}{l}\text { 11) Do you remember what were the fish consumed in the last three } \\
\text { meals of your home? }\end{array}$ & & & \\
\hline 11.a) Can you tell the weight of the fish? $(\mathrm{kg})$ & & & \\
\hline
\end{tabular}

12) Compared to 10 years ago, the fish consumption in your home:

$\square$ Increase $\square$ Decrease $\square$ The same

12.a) Why?

12.b) If changed, what was the frequency of fish consumption 10 years ago?

$\square$ Never $\square$ Rarely $\square$ Once a week $\square$ Almost every day $\square$ Everyday

\begin{tabular}{|l|c|c|c|}
\hline \multicolumn{1}{|c|}{} & $1^{\circ}$ & $2^{\circ}$ & $3^{\circ}$ \\
\hline 12.c) Do you remember which fish were consumed at that time? & & & \\
\hline 12.e) Do you still eat these fishes? & & & \\
\hline 12.f) Do you remember the weight of the fish? & & & \\
\hline
\end{tabular}

